\title{
POLYEMBRYONY IN ANGIOSPERMOUS TREES OF THE BRAZILIAN CERRADO AND CAATINGA VEGETATION
}

\author{
Antonieta N. Salomão ${ }^{1}$ \\ Antonio C. Allem ${ }^{1}$
}

Recebido em 29/09/00. Aceito em 25/07/01.

\begin{abstract}
The occurrence of polyembryony was investigated in 75 woody species of the Cerrado in central Brazil and the xerophilous Caatinga vegetation in northeastern Brazil. Fourteen species showed polyembryony, a type of anomalous angiospermous reproduction. Polyembryony is reported for the first time for nine genera, Astronium, Byrsonima, Cariniana, Copaifera, Hancornia, Magonia, Myracrodruon, Tabebuia, and Tapirira. The positive correlation found between polyembryony, sexual reproduction, and apomictic processes suggests that a number of angiospermous species may make regular use of multiple breeding systems.

Keywords - angiosperms, agamospermy, apomixis, polyembryony, Brazilian neotropics

RESUMO - A ocorrência de poliembrionia foi investigada em 75 espécies lenhosas do Cerrado do Brasil central e da Caatinga xerófila do nordeste brasileiro. Quatorze espécies apresentaram poliembrionia, uma modalidade de reprodução anômala em angiospermas. Poliembrionia é relatada pela primeira vez para nove gêneros, Astronium, Byrsonima, Cariniana, Copaifera, Hancornia, Magonia, Myracrodruon, Tabebuia e Tapirira. A correlação positiva encontrada entre poliembrionia, reprodução sexual e processos apomíticos sugere que parte das espécies de angiospermas faça uso regular de sistemas de cruzamento múltiplos.
\end{abstract}

Palavras-chave - angiospermas, agamospermia, apomixia, poliembrionia, neotrópico brasileiro

1. Embrapa Recursos Genéticos e Biotecnologia, C. P. 02372, 70849-970 Brasília DF e-mail: antoniet@cenargen.embrapa.br 


\section{Introduction}

Flowering plants (angiosperms) reproduce through sexual (amphimictic) and asexual (apomictic) processes. Apomixis (asexual seed development or agamospermy, with three main mechanisms, apospory, diplospory, and adventitious embryony), polyspory (bispory and tetraspory), and polyembryony (the formation of more than one embryo per ovule) are the three most common forms of angiospermous anomalous reproduction (Carman 1997).

A number of recent studies showed the existence of apomixis in shrubs and trees of Cerrado (Oliveira et al. 1992; Saraiva et al. 1996; Goldenberg \& Shepherd 1998), the rutaceous treelet Galipea jasminiflora in the state of São Paulo (Piedade \& Ranga 1993), as well as the melastomaceous tree Henriettea succosa in a remnant of neotropical forest near the city of Recife (Melo \& Machado 1996). Comparatively, research on polyembryony in woody species from the Brazilian neotropics has lagged behind. This study aims at documenting polyembryony in neotropical Brazilian trees.

\section{Material and methods}

Polyembryony was observed in 75 species belonging to 28 angiosperm families (Table 1). Seeds were collected from different vegetation forms of the Brazilian biomes Cerrado and Caatinga in the states of Bahia, Goiás, Minas Gerais, and Pernambuco. Germination tests were conducted with four replications of 20 or 25 seeds, moistened towel paper, in a chamber at $25^{\circ} \mathrm{C}$ incubation temperature. The experiments took place from 1992 through 1999. Polyembryony was counted positive when two or more seedlings emerged from individually germinated seeds. Specimen vouchers were deposited at the Embrapa Recursos Genéticos e Biotecnologia herbarium (CEN) in Brasilia ( $S$ $=$ leafless individuals with fruits only (voucher not made). JAS=José Alves da Silva.
SPCS=Sebastião Pereira Cordovil Silva. $\mathrm{BW}=$ Bruno M. T.. Walter. AAS=Aécio Amaral dos Santos. GPS=Glocimar Pereira da Silva. $\mathrm{TBC}=$ Taciana Barbosa Cavalcanti. ACS $=$ Anderson Cássio Sevilha ).

\section{Results and Discussion}

Polyembryony was recorded in 14 arboreal species in 12 angiosperm families, i.e. close to 20 per cent of the species examined (Table 2).

Seedlings from the same seed showed uniform development in Genipa americana, Cariniana estrellensis, Hancornia speciosa, Tabebuia ochracea, Copaifera langsdorffii, and Acacia polyphylla. Seedlings from the other polyembryonic species varied in development, particularly in size (Figs. 1 and 2).

Nine genera do not appear in Carman's (1997) comprehensive review on polyembryony and apomixis. This study represents the first record of polyembryony for the following angiosperm woody genera: Astronium, Byrsonima, Cariniana, Copaifera, Hancornia, Magonia, Myracrodruon, Tabebuia, and Tapirira.

The association recorded for polyembryony, gametophytic apomixis, and polyploidy (Mogie 1992; Asker \& Jerling 1992; Carman 1997) suggests that a number of angiosperm species may make regular use of mixed mating systems to perpetuate themselves. This hypothesis is confirmed for three of the 14 polyembryonic species documented in this communication. These species tested positive in the field for functional (autonomous) apomixis, through bagging experiments, Astronium fraxinifolium (Allem 1991), Eriotheca pubescens (Oliveira et al. 1992), and Genipa americana (Crestana 1995).

The occurrence of polyembryony in Commiphora lepthophloeos from Caatinga suggests that this species may also be apomictic since Commiphora whigtii, in India, has shown both anomalies simultaneously (Gupta et al. 1996). It is widely believed that most if not all 

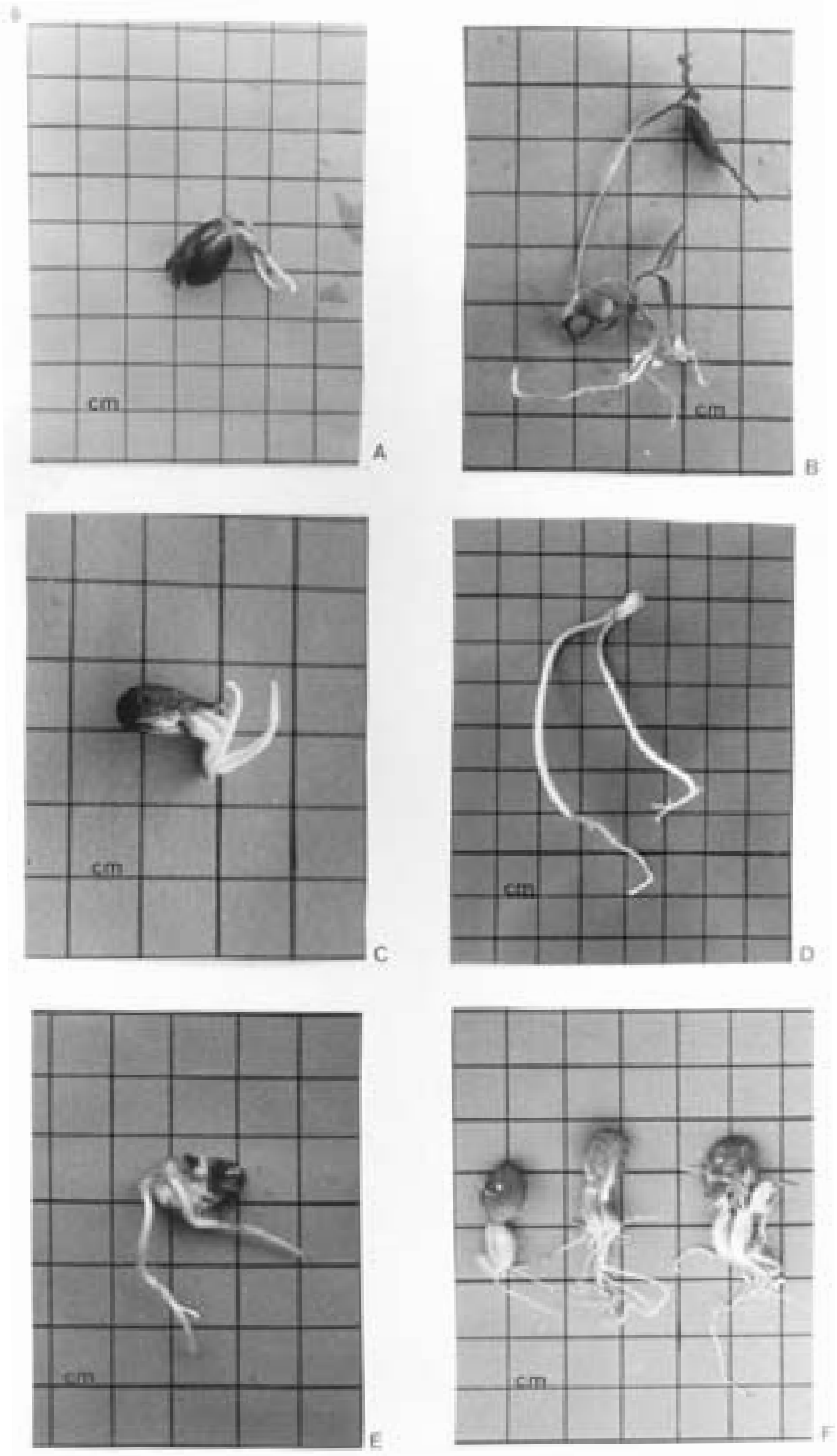

Fig. 1. Polyembryonic seedlings of woody angiospermous species of the Brazilian Cerrado and Caatinga. A, Copaifera langsdorffii, 7-day old; B, Tapirira guianensis, 20-day old; C, Cariniana estrellensis, 7-day old; D, Genipa americana, 12-day old; E, Acacia polyphylla, 10-day old; F, Hancornia speciosa, 12-day old. 

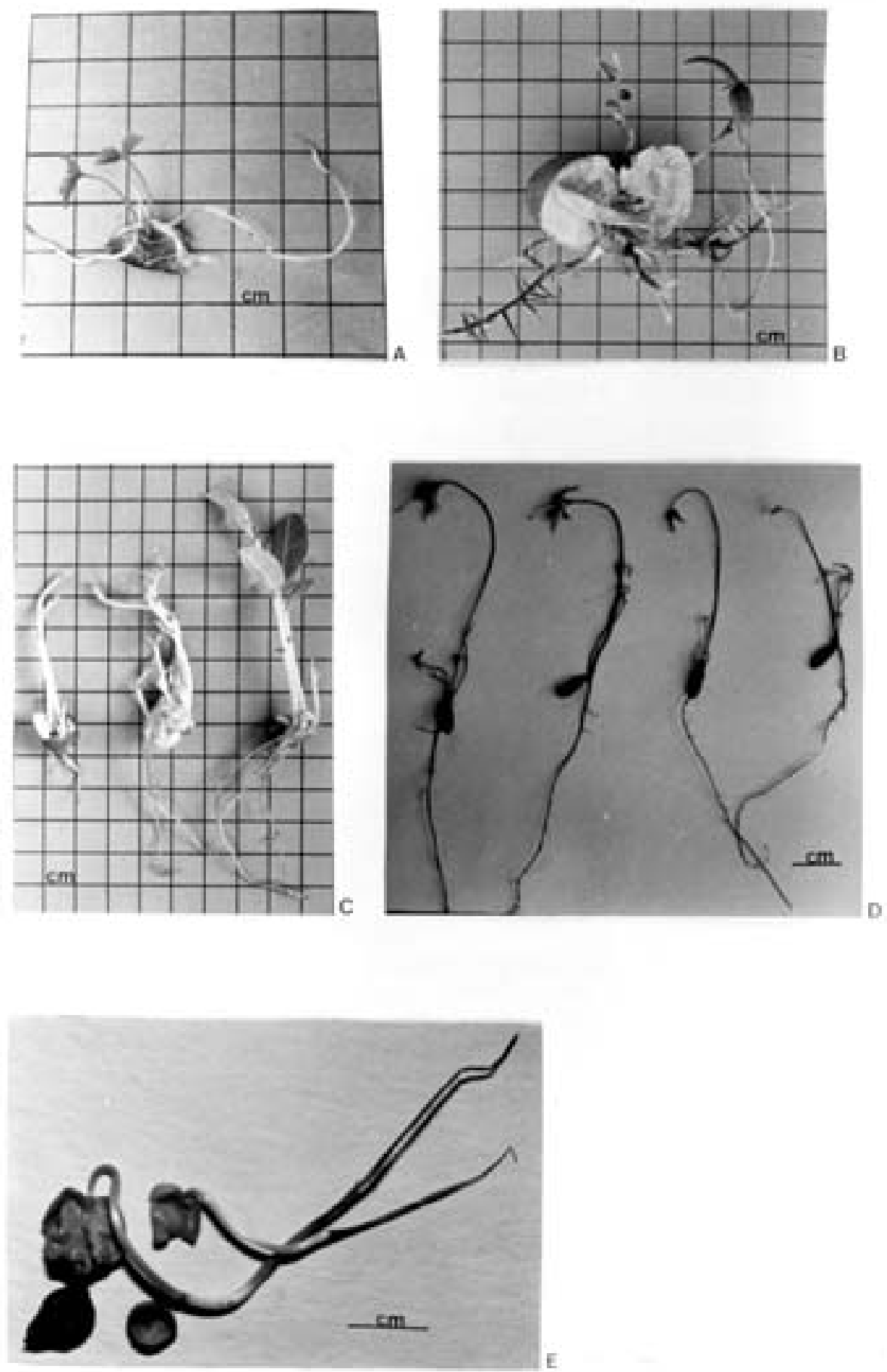

Fig. 2. Polyembryonic seedlings of woody angiospermous species of the Brazilian Cerrado and Caatinga. A, Tabebuia ochracea, 18-day old; B, Magonia pubescens, 20-day old; C, Eriotheca pubescens, far right seedlings 20-day old; D, Astronium fraxinifolium, 12-day old; E, Commiphora lepthophloeos, 20-day old. 
apomicts are facultative sexuals (Asker \& Jerling 1992; Carman 1997).

Apomictic speciation is suspected to occur in a number of angiosperm groups (UrbanskaWorytkiewicz 1974). Her thought has been strenghtened by Carman's (1997) double conclusion that an apomictic evolutionary trend seems discernible in part of the angiosperms, while apomixis may eventually act as the springboard toward the formation of new angiosperm genera and species.

As recently as 1979, examples of apomixis in the tropics came principally from weeds or from well-documented case-studies in Andropogoneae and Paniceae (Connor 1979). As late as 1992, comprehensive treatments on apomixis (Mogie 1992; Asker \& Jerling 1992) showed virtually nothing on arboreal apomixis in the tropics.

This showed that compilative efforts were not being coordinated. Another example that compilations may not be representative of the real incidence of the phenomenon in angiosperms is from the Anacardiaceae, Naumova (1993) lists in her review one genus, Carman
(1997) lists two, while Tisserat et al. (1979) list three. Figures available for angiosperm apomixis differ considerably in the larger treatments. Khokhlov (1976) states that 80 families and over 300 genera present apomixis. Tisserat et al. (1979) updated the 37 families reported by Nygren (1954) and indicated 59 families and 138 genera. Naumova (1993) only tabulated adventitious embryony and registered 57 families, 121 genera, and 250 species.

She regards instances of adventitious embryony as de facto evidence that apomixis simultaneously occurred in the species, since at least one adventitious polyembryonic seedling is asexual. By implication, all 250 species compiled by her are at least facultative apomicts.

A similar viewpoint was taken by Koltunow (1993) who, following Asker \& Jerling (1992), stated that most plants with gametophytic apomixis (apospory and diplospory) are polyploids, while genera with adventitious embryony (a third apomictic mechanism also known as sporophytic apomixis) are ordinarily diploids. The latest comprehensive treatment on anomalous angiospermous reproduction (Carman

Table 2. Polyembryonic species of the Cerrado and Caatinga vegetations. $\mathrm{Ce}=\mathrm{Cerrado} ; \mathrm{Ca}=\mathrm{Caatinga} ; \mathrm{T}=$ tree; $\mathrm{S}=$ shrub; $\mathrm{D}=$ dioecious; $\mathrm{M}=$ monoecious hermaphroditic; $\mathrm{P}=$ polyembryony; $\mathrm{A}=$ apomixis. * Polyembryony recorded in seed lot from Caatinga.

\begin{tabular}{|c|c|c|c|c|c|c|c|}
\hline Family & Species & Biome & Habit & Sex & Anomaly & Seedlings & $\mathrm{P}(\%)$ \\
\hline \multirow[t]{3}{*}{ Anacardiaceae } & Astronium fraxinifolium & $\mathrm{Ce}, \mathrm{Ca}$ & $\mathrm{T}$ & $\mathrm{D}$ & $\mathrm{P}, \mathrm{A}$ & 2 to 4 & 4 \\
\hline & Myracrodruon urundeuva* & $\mathrm{Ce}, \mathrm{Ca}$ & $\mathrm{T}$ & $\mathrm{D}$ & $\mathrm{P}$ & 2 & 2 \\
\hline & Tapirira guianensis & $\mathrm{Ce}$ & $\mathrm{T}$ & M & $\mathrm{P}$ & 2 & 2 \\
\hline Apocynaceae & Hancornia speciosa & $\mathrm{Ce}, \mathrm{Ca}$ & $\mathrm{S} / \mathrm{T}$ & $\mathrm{M}$ & $\mathrm{P}$ & 2 to 3 & 5 \\
\hline Bignoniaceae & Tabebuia ochracea & $\mathrm{Ce}$ & $\mathrm{S} / \mathrm{T}$ & $\mathrm{M}$ & $\mathrm{P}$ & 2 to 4 & 3 \\
\hline Bombacaceae & Eriotheca pubescens & $\mathrm{Ce}$ & $\mathrm{T}$ & $\mathrm{M}$ & $\mathrm{P}, \mathrm{A}$ & 2 to 6 & 3 \\
\hline Burseraceae & Commiphora lepthophloeos* & $\mathrm{Ce}, \mathrm{Ca}$ & $\mathrm{S} / \mathrm{T}$ & $\mathrm{D}$ & $\mathrm{P}$ & 2 & 2 \\
\hline Caesalpinaceae & Copaifera langsdorffii & $\mathrm{Ce}, \mathrm{Ca}$ & $\mathrm{T}$ & $\mathrm{M}$ & $\mathrm{P}$ & 2 & 1 \\
\hline Lecythidaceae & Cariniana estrellensis & $\mathrm{Ce}$ & $\mathrm{T}$ & $\mathrm{M}$ & $\mathrm{P}$ & 2 & 1 \\
\hline Malpighiaceae & Byrsonima basiloba & $\mathrm{Ce}$ & $\mathrm{S}$ & $\mathrm{M}$ & $\mathrm{P}$ & 2 & 3 \\
\hline Mimosaceae & Acacia polyphylla & $\mathrm{Ce}, \mathrm{Ca}$ & $\mathrm{T}$ & $\mathrm{M}$ & $\mathrm{P}$ & 2 & 2 \\
\hline Rhamnaceae & Zizyphus joazeiro & $\mathrm{Ca}$ & $\mathrm{T}$ & $\mathrm{M}$ & $\mathrm{P}$ & 2 & 2 \\
\hline Rubiaceae & Genipa americana & $\mathrm{Ce}, \mathrm{Ca}$ & $\mathrm{T}$ & $\mathrm{D}$ & $\mathrm{P}, \mathrm{A}$ & 2 & 3 \\
\hline Sapindaceae & Magonia pubescens & $\mathrm{Ce}, \mathrm{Ca}$ & $\mathrm{S} / \mathrm{T}$ & $\mathrm{M}$ & $\mathrm{P}$ & 2 to 3 & 3 \\
\hline
\end{tabular}


1997) tabulated reproductive data of 348 angiosperm families and obtained the following results: 1) apomixis exists in 126 genera of 33 families; 2) adventitious embryony exists in 53 families; 3) polyembryony was the most common anomaly recorded, occurring in 255 genera of 115 families and 4) at least one form of anomalous reproduction was found in 506 genera of 163 families (Table 3).

The possibility that the occurrence of polyembryony may regularly indicate the simultaneous presence of apomixis in the species (Hanna \& Bashaw 1987; Carman 1997) is a working hypothesis worth further investigation. If true, figures for both angiospermous polyembryony and apomixis are likely to increase.

Carman (1997) recorded 33 apomictic families. He regarded apomixis as composed of two main mechanisms, apospory and diplospory.

Table 3. Apomixis in angiosperms.

\begin{tabular}{lcl}
\hline Families & Genera & Reference \\
\hline 80 & 300 & Khokhlov (1976) \\
59 & 138 & Tisserat et al. (1979) \\
36 & 300 & Hanna \& Bashaw \\
$(1987)$ & & \\
57 & 121 & Naumova (1993) \\
33 & 126 & Carman (1997) \\
\hline
\end{tabular}

Because he considered adventitious embryony a form of polyembryony, he separately listed 53 distinct angiosperm families with this reproductive anomaly. However, a number of authors (e.g., Baker et al. 1983; Naumova 1993; Koltunow 1993) regard adventitious embryony as a third major process of apomixis. If this latter interpretation is used, Carman's figures on apomixis increase to 86 angiosperm families, a figure remarkably similar to that held by
Khokhlov for angiosperms (Table 3). Moreover, if this thinking holds, it means that a quarter of all families of flowering plants contain apomictic genera and species, i.e. 80-86 families out of 348 tabulated. In addition, considering that there exists 460 angiosperm families and that reproductive data are missing for 112 of them (Carman 1997), it is only appropriate to await further studies of anomalous angiosperm reproduction before making a final conclusion.

Future reviews will in all likelihood expand the above figures. A randomly-chosen indication of this trend, there has been the recent report of apomixis in five Boehmeria species (Zang \& Zhao 1996). This figure is significant since it amounts to $10 \%$ of the species of the genus. Forthcoming comprehensive reviews on the angiosperms are expected to disclose more apomictic families, genera and species. For example, apomixis exists in the euphorbiaceous herb Phyllanthus odontadenius (Bancilhon 1971), as well as in the herbaceous weedy species $P$. amarus; however, the genus Phyllanthus does not appear in any of the studies examined in this text. Another example, Vochysia tucanorum, a tree from Cerrado, is a facultative apomict (Costa et al. 1992). That was the first record of apomixis for the family Vochysiaceae, which, likewise, is missing in all of the above discussed treatments.

\section{Acknowledgments}

We are indebted to B. M. T. Walter., J.A.da Silva, A.A. Santos, S.P.C.Silva, G.P. Santos, T.B. Cavalcanti, and A. C. Sevilha for seed supply.

We are most grateful to two anonymous referees, who greatly improved the quality of the text. 


\section{Bibliographic references}

Allem, A.C. 1991. Estudo da biologia reprodutiva de duas espécies florestais (aroeira e gonçalo-alves) da região do cerrado. Pesquisa em andamento, CENARGEN, 2: 1-5.

Asker, S.E. \& Jerling, L. 1992. Apomixis in plants. CRC Press, Boca Raton, Florida.

Baker, H.G., Bawa, K.S., Frankie, G.W. \& Opler, P.A. 1983. Reproductive biology of plants in tropical forests. In F.B. Golley, Tropical Rain Forest Ecosystems: Structure and Function, pp. 183-215. Elsevier, Amsterdam.

Bancilhon, L. 1971. Contribution à l'etude taxonomique du genre Phyllanthus (Euphorbiaceae). Boissiera 18: 1-81. pls. 1-22.

Carman, J.G. 1997. Asynchronous expression of duplicate genes in angiosperms may cause apomixis, bispory, tetraspory, and polyembryony. Biological Journal of the Linnean Society 61: 51-94.

Connor, H.E. 1979. Breeding systems in the grasses: a survey. New Zealand Journal of Botany 17: 547574.

Costa, R.B., Kageyama, P.Y. \& Mariano, G. 1992. Estudo do sistema de cruzamento de Anadenanthera falcata Benth., Vochysia tucanorum Mart. e Xylopia aromatica Baill. em área de cerrado. Revista Brasileira de Sementes 14: 93-96.

Crestana, C.M.S. 1995. Ecologia da polinização de Genipa americana L. (Rubiaceae) na estação ecológica de Moji-Guaçu, estado de São Paulo. Revista do Instituto Florestal 7: 169-195.

Goldenberg, R. \& Shepherd, G.J. 1998. Studies on the reproductive biology of Melastomataceae in "cerrado" vegetation. Plant Systematics and Evolution 211: 13-29.

Gupta, P., Shivanna, K.R. \& Ram, H.Y.M. 1996. Apomixis and polyembryony in the guggul plant, Commiphora wightii. Annals of Botany 78: 67-72.

Hanna, W.W. \& Bashaw, E.C. 1987. Apomixis: its identification and use in plant breeding. Crop Science 27: 1136-1139.

Khokhlov, S.S. 1976. Evolutionary-genetic problems of apomixis in angiosperms. In S.S. Khokhlov, Apomixis and Breeding, pp. 3-17. Amerind, New Delhi (translated from the Russian by B.R. Sharma and published for the Agricultural Research Service, USDA).

Koltunow, A.M. 1993. Apomixis: embryo sacs and embryos formed without meiosis or fertilization in ovules. The Plant Cell 5: 1425-1437.
Melo, G.F.A. \& Machado, I.C. 1996. Biologia da reprodução de Henriettea succosa DC. (Melastomataceae). Revista Brasileira de Biologia 56: 383-389.

Mogie, M. 1992. The Evolution of Asexual Reproduction in Plants. Chapman and Hall, London.

Naumova, T.N. 1993. Apomixis in Angiosperms: Nucellar and Integumentary Embryony. CRC Press, Boca Raton, Florida.

Nygren, A. 1954. Apomixis in the angiosperms. II. The Botanical Review 20: 577-649.

Oliveira, P.E., Gibbs, P.E., Barbosa, A.A. \& Talavera, S. 1992. Contrasting breeding systems in two Eriotheca (Bombacaceae) species of the Brazilian cerrados. Plant Systematics and Evolution 179: 207-219.

Piedade, L.H. e Ranga, N.T. 1993. Ecologia da polinização de Galipea jasminiflora Engler (Rutaceae). Revista Brasileira de Botânica 16: 151158.

Saraiva, L.C., Cesar, O. \& Monteiro, R. 1996. Breeding systems of shrubs and trees of a Brazilian savanna. Arquivos de Biologia e Tecnologia, São Paulo, 39: 751-763.

Tisserat, B., Esan, E.B. \& Murashige, T. 1979. Somatic embryogenesis in angiosperms. Horticultural Review 1: 1-78.

Urbanska-Worytkiewicz, K. 1974. L'agamospermie, système de reproduction important dans la spéciation des angiospermes. Bulletin de la Societé Botanique de France 12: 329-346.

Zang, G.G. \& Zhao, T.N. 1996. Preliminary report of agamic complex in Boehmeria. China's Fibre Crops 1: 19. [in Chinese]. 
Table 1. Angiospermous species tested for the presence of polyembryony.

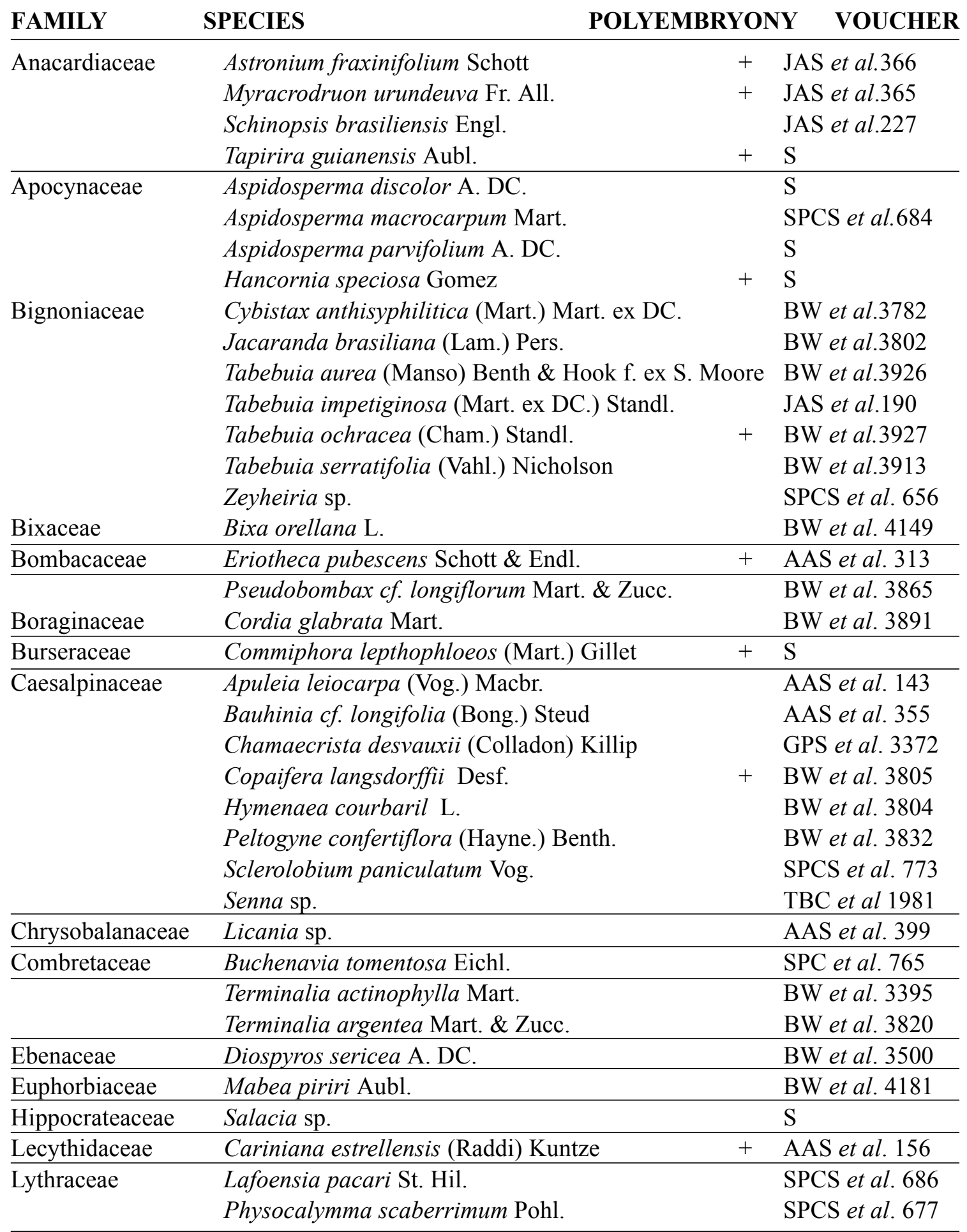


Table 1. (Cont.)

\begin{tabular}{|c|c|c|c|}
\hline FAMILY & SPECIES & YOP & VOUCHER \\
\hline Malpighiaceae & Byrsonima basiloba A. Juss. & + & SPCS et al. 467 \\
\hline \multirow[t]{10}{*}{ Mimosaceae } & Acacia polyphylla A. DC. & + & ACS et al. 1828 \\
\hline & Anadenanthera macrocarpa (Benth.) Brenan & & GPS et al. 3600 \\
\hline & Dimorphandra mollis Benth. & & BW et al. 3780 \\
\hline & Enterolobium contortisiliquum (Vell.) Morong. & & BW et al. 3830 \\
\hline & Enterolobium gummiferum (Mart.) Macbr. & & BW et al. 4247 \\
\hline & Inga cylindrica (Vell.) Mart. & & SPCS et al. 712 \\
\hline & Inga ingoides (Rich.) Willd. & & BW et al. 4050 \\
\hline & Mimosa $\mathrm{sp}$ & & TBC et al. 1961 \\
\hline & Plathymenia reticulata Benth. & & BW et al. 4221 \\
\hline & Stryphnodendron polyphyllum Mart. & & BW et al. 4252 \\
\hline Monimiaceae & Siparuna guianensis Albl. & & GPS et al. 3589 \\
\hline \multirow[t]{2}{*}{ Myrtaceae } & Campomanesia adamantium M. Camb. & & AAS et al. 23 \\
\hline & Eugenia dysenterica DC. & & $\mathrm{S}$ \\
\hline \multirow[t]{7}{*}{ Papilionaceae } & Amburana cearensis (Fr. All.) A.C. Smith & & JAS et al. 275 \\
\hline & Bowdichia virgilioides HBK & & SPCS et al. 767 \\
\hline & Dipteryx alata Vog. & & BW et al. 4248 \\
\hline & Machaerium acutifolium Vog. & & BW et al. 4178 \\
\hline & Machaerium angustifolium Vog. & & BW et al. 3342 \\
\hline & Ormosia fastigiata Tul. & & BW et al. 2700 \\
\hline & Pterodon emarginatus Vog. & & BW et al. 3346 \\
\hline Polygonaceae & Triplaris gardneriana Wedd. & & BW et al. 3900 \\
\hline Rhamnaceae & Zizyphus joazeiro Mart. & + & $\mathrm{S}$ \\
\hline \multirow[t]{4}{*}{ Rubiaceae } & Genipa americana $\mathrm{L}$. & + & $\mathrm{S}$ \\
\hline & Guettarda pohliana Muell. Arg. & & TBC et al. 1932 \\
\hline & Palicourea rigida Kunth & & SPCS et al. 741 \\
\hline & Tocoyena formosa (Cham. \& Schlecht) K. Schur & $\mathrm{CS}$ & et al. 565 \\
\hline \multirow[t]{3}{*}{ Sapindaceae } & Magonia pubescens Benth. & + & AAS et al. 343 \\
\hline & Sapindus saponaria $\mathrm{L}$. & & BW et al. 3915 \\
\hline & Talisia cf. esculenta (A.St.Hil.) Radlk. & & AAS et al. 41 \\
\hline \multirow[t]{3}{*}{ Sterculiaceae } & Guazuma ulmifolia Lam. & & BW et al.3821 \\
\hline & Helicteres corylifolia Nees \& Mart. & & BW et al. 3911 \\
\hline & Sterculia striata St. Hil. & & BW et al. 3907 \\
\hline Styracaceae & Styrax camporum Pohl. & & $\mathrm{S}$ \\
\hline Tiliaceae & Apeiba tibourbou Aubl. & & GPS et al. 3553 \\
\hline
\end{tabular}


